\section{Tenascin and Fibronectin Expression after Pulp Capping with Different Hemostatic Agents: A Preliminary Study}

Elaine Zanchin Baldissera ${ }^{1}$, Adriana Fernandes da Silva' ${ }^{1}$ Ana Paula Neutzling Gomes ${ }^{1}$, Adriana Etges ${ }^{1}$, Tatiana Botero² ${ }^{2}$ Flávio Fernando Demarco ${ }^{1}$, Sandra Beatriz Chaves Tarquinio ${ }^{1}$
'Graduate Program in Dentistry, UFPel - Federal University of Pelotas, Pelotas, RS, Brazil 'University of Michigan, Cariology, Restorative Science and Endodontics Department, Ann Arbor, MI, USA

Correspondence: Profa. Dra Sandra B. C. Tarquinio, Rua Gonçalves Chaves, 457, $5^{\circ}$ andar, Centro, 96015-568 Pelotas, RS, Brasil. Tel: +55-533222-6690. e-mail: sbtarquinio@ gmail.com; ffdemarco@gmail.com

\begin{abstract}
This study investigated the expression of extracellular matrix glycoproteins tenascin (TN) and fibronectin $(\mathrm{FN})$ in pulp repair after capping with calcium hydroxide $(\mathrm{CH})$, following different hemostasis protocols. Class I cavities with a pulp exposure were prepared in 42 human third molars scheduled for extraction. Different hemostatic agents (0.9\% saline solution, 5.25\% sodium hypochlorite and 2\% chlorhexidine digluconate) were used and pulps were capped with $\mathrm{CH}$ cement. After 7, 30 or 90 days, teeth were extracted, formalin-fixed, and prepared for immunohistochemical technique. Hemostatic agents did not influence the expression of TN and FN. Both glycoproteins were found in the entire the pulp tissue and around collagen fibers, but were absent in the mineralized tissues. In the predentin, TN showed positive immunostaining and FN had a variable expression. Within 7 days post-treatment, a slightly more pronounced immunostaining on the pulp exposure site was observed. Within 30 days, TN and FN demonstrated a positive expression around the dentin barrier and at 90 days, a thin and linear expression of TN and FN was delimitating the reparative dentin. In conclusion, hemostatic agents did not influence $\mathrm{TN}$ and FN expression. Immunostaining for TN and FN was seen in different regions and periods, demonstrating their role in pulp repair.
\end{abstract}

Key Words: dental pulp capping, calcium hydroxide, extracellular matrix.

\section{Introduction}

Maintaining the pulp viability is the aim of vital pulp therapy strategies. Despite the good results obtained with mineral trioxide aggregate (MTA), calcium hydroxide (CH)based materials are still considered a good option to protect the pulp tissue directly $(1,2)$.

A paramount condition for direct pulp capping success is the control of bleeding following pulp exposure (3). One of the most common substances to control pulp bleeding is saline solution, which sometimes may be ineffective (3). While the use sodium hypochlorite ( $\mathrm{NaOCl}$ ) has been proven successful to control bleeding in direct adhesive capping in one study (4), another investigation found unsatisfactory results (5). Similarly, the use of 2\% chlorhexidine digluconate as an hemostatic agent showed disastrous results before adhesive capping (6). In opposite, similar histological findings were observed in direct pulp capping with $\mathrm{CH}$, when using $\mathrm{NaOCl}$, chlorhexidine and saline as hemostatic solutions (7).

Extracellular matrix (EM) has an important role in the secondary and tertiary dentin formation (8). Fibronectin (FN) and tenascin (TN) are two major glycoproteins of the $E M$, mediating a series of cellular interactions, with an important participation during tissue development, cell migration, adhesion and differentiation (9). Studies have investigating TN and FN expression after pulp capping with $\mathrm{CH}$ or MTA and using saline as the hemostatic agent, in human or swine teeth $(1,10)$ suggested that differentiation of the odontoblast could be regulated by the expression of these two glycoproteins. However, the potential effect of other hemostatic agents on EM components has not been investigated.

The aim of this study was to investigate TN and FN expression in pulps capped with $\mathrm{CH}$ after using three hemostatic agents.

\section{Material and Methods \\ Experimental Design and Direct Pulp-Capping Procedures}

The research was approved by the Ethics Committee of the Federal University of Pelotas, Brazil and the participants signed an informed consent form. The operative procedures and morphological findings were previously described (7). Briefly, 42 human maxillary third molars scheduled for extraction due to orthodontic reasons were selected (mean age $23 \pm 2.59$ years). Under local anesthesia and rubber dam isolation, Class I cavities were prepared with a pulp exposure, under air-water cooling. The cavities were randomly divided into three groups according to the different hemostatic agents: $0.9 \%$ saline solution, 5.25\% 
$\mathrm{NaOCl}$ and $2 \%$ chlorhexidine digluconate (Table 1). After bleeding control, CH cement (Dycal; Dentsply Ind. e Com. Ltda, Petrópolis, RJ, Brazil) was applied and cavities were properly restored with adhesive system (Single Bond; 3M ESPE, St Paul, MN, USA) and composite resin (Filtek Z250; $3 \mathrm{M}$ ESPE). Teeth were extracted at three post-operative intervals.

\section{Histopathological Preparation}

Following extraction, performed after 7, 30, and 90 days of treatment, the teeth were fixed in 10\% formalin solution for $48 \mathrm{~h}$ and then demineralized in 20\% formic acid. Specimens were paraffin-embedded and serially cut into 3- $\mu \mathrm{m}$-thick sections.

\section{Immunohistochemical Staining}

Sections adjacent to HE-stained sections were used for the immunohistochemical technique. They were deparaffinized in xylene and rehydrated in 100, 90 and $70 \%$ alcohol, distilled water $\left(\mathrm{dH}_{2} \mathrm{O}\right)$ and washed in phosphatebuffered saline (PBS) for 5 min, consecutively. All primary antibodies were diluted in PBS containing 0.1\% BSA (bovine serum albumin).

Then, the sections were washed in methanol with $3 \%$ hydrogen peroxide $\left(\mathrm{H}_{2} \mathrm{O}_{2}, 1: 1\right)$ twice for 5 min to block endogenous peroxidase activity and then washed in PBS. The antigenic retrieval was done incubating the sections with 1\% pepsin for fibronectin, and $0.5 \%$ pepsin for tenascin, both at $37^{\circ} \mathrm{C}$, respectively for 60 and $30 \mathrm{~min}$. The sections were incubated with the primary antibodies anti-fibronectin (Dako; AIS, Glostrup, Denmark) $(1: 1,200)$ for 120 min at $37^{\circ} \mathrm{C}$, and anti-tenascin (Sigma Chemical Co., St. Louis, MO, USA) $(1: 3,000)$ at $4^{\circ} \mathrm{C}$ overnight. After that, the incubation of biotinylated goat anti-rabbit/ mouse secondary antibody (Dako) was performed (1:100) for $30 \mathrm{~min}$, followed by incubation with streptavidin-biotin complex (SABC) (Dako,) for 30 min. After each step, the sections were washed twice in PBS. Specific immunostaining was visualized by incubation with 3,3'-diaminobenzidine

Table 1. Study design

\begin{tabular}{lccc}
\hline \multirow{2}{*}{ Group } & \multicolumn{3}{c}{ Number of specimen/period } \\
\cline { 2 - 4 } & 7 days $(\mathrm{n}=14)$ & 30 days $(\mathrm{n}=14)$ & 90 days $(\mathrm{n}=14)$ \\
\hline $\begin{array}{l}\text { 0.9\% saline } \\
\text { solution* }(\mathrm{n}=14)\end{array}$ & $\mathrm{n}=4$ & $\mathrm{n}=5$ & $\mathrm{n}=5$ \\
$\begin{array}{l}5.25 \% \text { sodium } \\
\text { hypochlorite }\end{array}$ & $\mathrm{n}=5 \mathrm{n})$ & $\mathrm{n}=5$ & $\mathrm{n}=4$ \\
$\begin{array}{l}\text { 2\% chlorhexidine } \\
\text { digluconate }\end{array}$ & $\mathrm{n}=5$ & $\mathrm{n}=4$ & $\mathrm{n}=5$ \\
\hline
\end{tabular}

*Áster Medical Products, SP, Brazil (batch 0944/08/T). **Prescription pharmacy (1S0 9002). ***FGM Produtos Odontológicos, Joinville, SC, Brazil (batch 30381). tetrachloride (DAB) containing $0.03 \% \mathrm{H}_{2} \mathrm{O}_{2}$ for 3 min and washed with $\mathrm{dH}_{2} \mathrm{O}$. The sections were counterstained with Mayer's hematoxylin solution for $10 \mathrm{~min}$, rinsed in running water, dehydrated in ethanol (70,90 and 100\%, respectively) for $3 \mathrm{~min}$ each and cleared with xylene. The slides were mounted and the sections were analyzed under light microscopy. The information regarding the used primary antibodies is presented in Table 2. Negative control staining was performed by omitting the incubation of the sections with the primary antibodies. Sections from mucosal tissues containing ulcerated areas, were used as positive controls. The ubiquity of the expression of TN and FN in blood vessels was also used as positive internal control.

\section{Immunohistochemical Expression Analysis}

A descriptive analysis of the TN and FN immunostaining patterns as well the immunolocation was performed for these glycoproteins in different dental tissues sites (pulp tissue, exposure area, dentin barrier, reactionary dentin, predentin and dentin). The analysis was carried out under light microscopy by two blinded calibrated examiners.

\section{Results}

In all specimens, in each investigated time period, the TN and FN expression patterns were similar regardless of the hemostatic agent used.

\section{Expression in the Pulp Tissue, Dentin Barrier and Reactionary Dentin}

Both glycoproteins were expressed in all pulp tissues, in the three investigated periods, located along with the collagen fibers and surrounding blood vessels (positive internal controls), with a reticular immunostaining pattern (Figs. 1 and 2). In areas of higher condensation of collagen fibers, especially under pulp exposure sites, there was higher TN and FN expression. After 7 days, TN (Fig. 1A and 1B) and FN (Fig. 2A and 2B) showed a slightly increased expression under the exposure site.

After 30 days, dentin barriers (osteodentin) and reactionary dentin were present in almost all specimens, and TN showed marked expression subjacent to these new mineralization zones (Fig. $1 \mathrm{C}$ to $1 \mathrm{E})$. Focal areas of TN immunoreactivity were also observed inside the reparative and reactionary dentin, which were in mineralization process (Fig. 1C to 1E). In the same period, there was no immunoreactivity of FN in the tertiary dentin (Fig. 2C and 2D). Nevertheless, in the pulp tissue subjacent to the tertiary dentin an evident reactivity of FN was detected (Fig. 2C and 2D), especially in the areas where the odontoblast-like cells were aligned. 

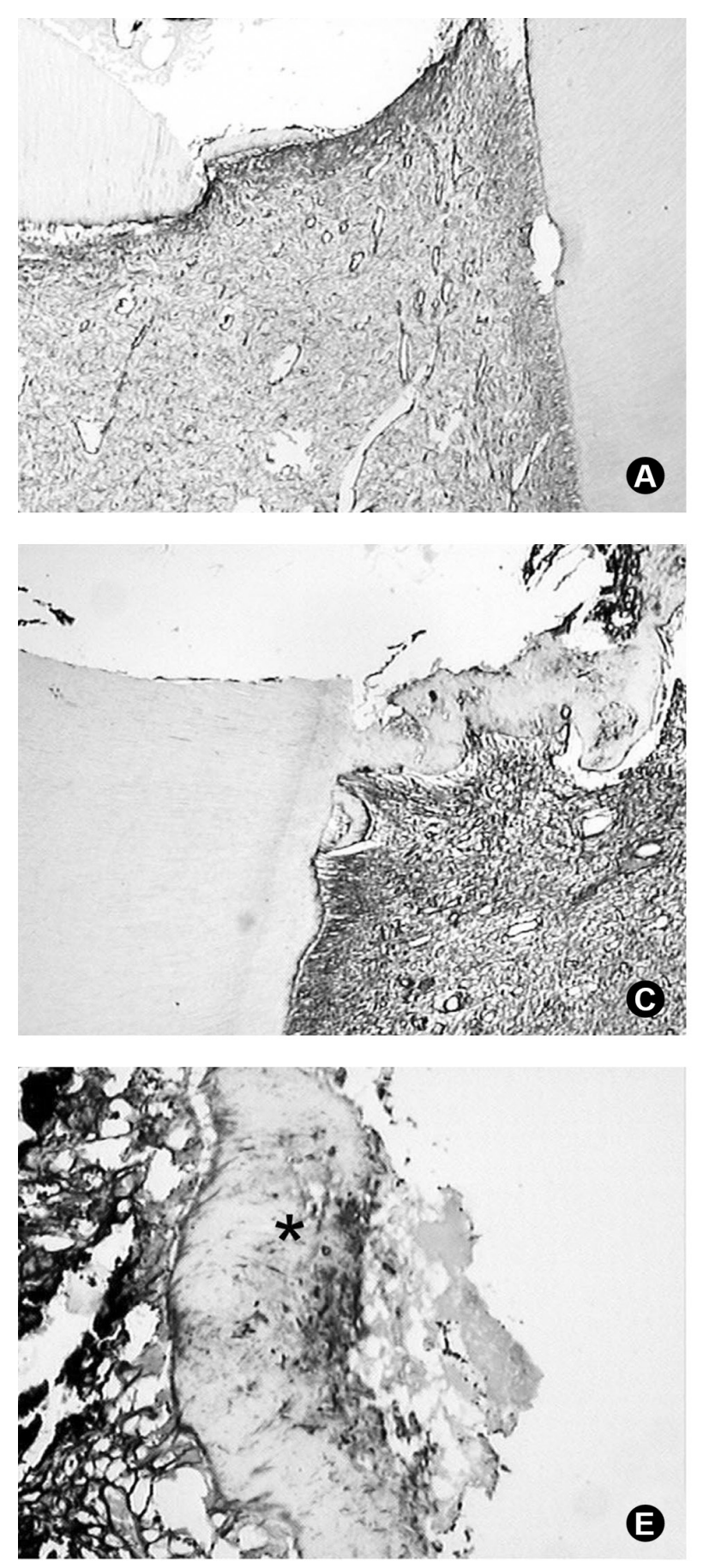

E

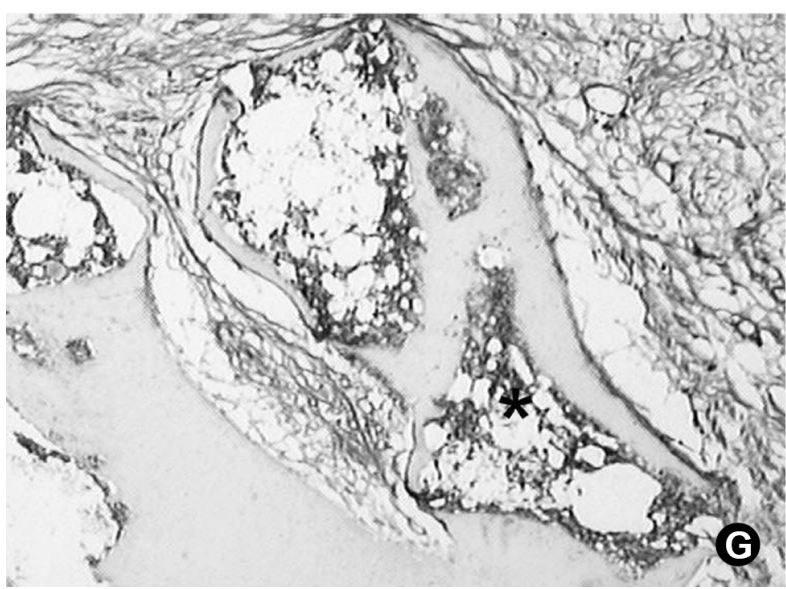

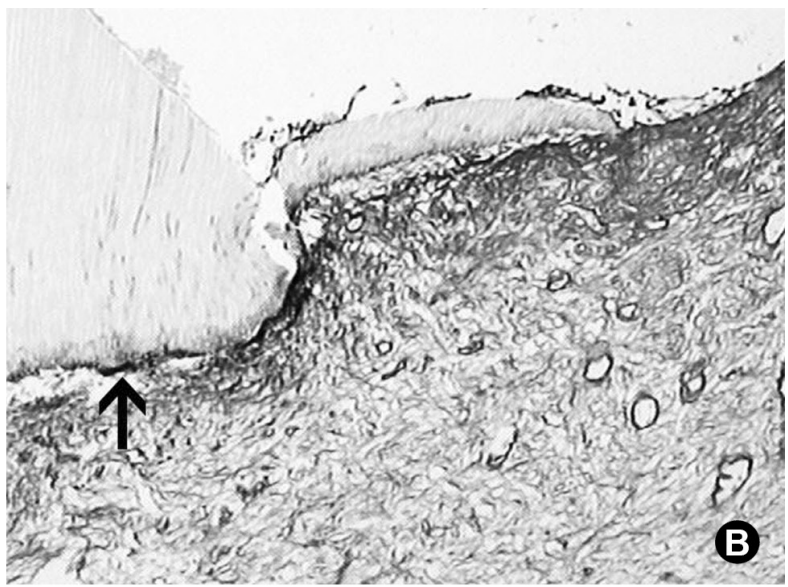
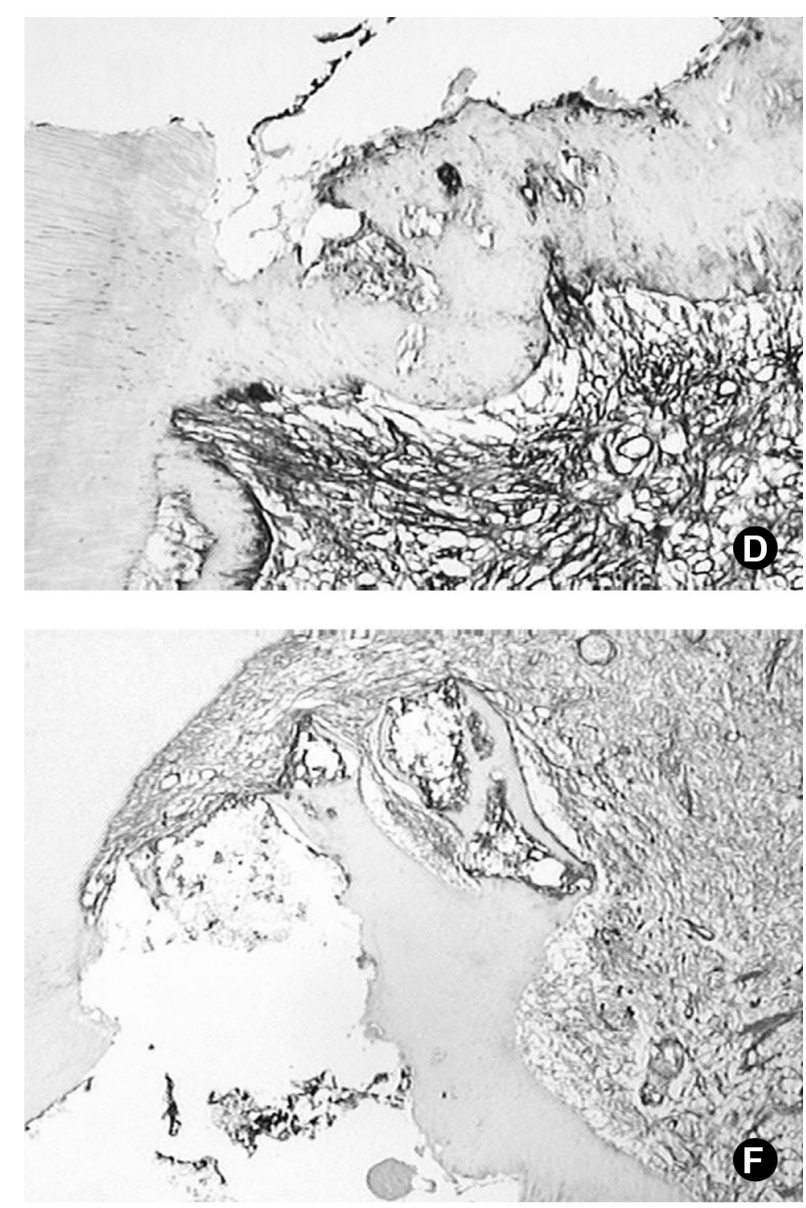

Figure 1. Immunohistochemical TN expression during pulp repair. A: TN expression in the entire pulp tissue, after 7 days of pulp capping (saline as hemostatic agent) close to the collagen fibers with a slight increase in the exposure site. Positive immunostaining in the predentin zone and around blood vessels (positive control), with no expression in primary and secondary dentin (40x). B: Higher magnification of 'A' at the exposure site, with marked TN immunoreactivity in the predentin (arrow) (100x). C: $\mathrm{NaOCl}$ (30 days). Dentin barrier with internal areas of focal TN immunoreactivity, also observed in the pulp tissue and predentin. Physiological dentin negative to TN staining (40x). D: Close view of TN expression in the dentin barrier and subjacent connective tissue (100x). E: Detail of the reparative dentin in ' $C$ ' and 'D', reinforcing the focal TN immunoreactivity in the dentin barrier $\left(^{*}\right)(200 \times)$. F: Saline (90 days). No TN expression in the mineralized tissues and TN immunoreactivity in the subjacent connective tissue and predentin (40x). G: Higher magnification of ' $F$ ' showing mature dentin barrier, negative for TN expression. Positive TN immunoreactivity $(*)$ in the neighboring pulp tissue (100x). 
At 90 days, a thin linear staining delimitating a dentin barrier subjacent area was observed for both TN (Figs. 1F and $1 \mathrm{G}$ ) and FN (Fig. 2E and 2F). Nevertheless, the two glycoproteins were not observed in the mineralized tissues: reactionary or reparative dentin (Fig. 1E to 1G).

\section{Predentin, Primary and Secondary Dentin}

In all the studied periods, TN showed reactivity at the predentin zone (Figs. 1A to 1C). In contrast, FN in predentin disclosed variable staining (Fig. 2E), sometimes being even absent (Fig. 2A and 2B). Throughout the study, in primary or secondary dentin there was no expression for TN (Fig. $1 \mathrm{~A}$ to $1 \mathrm{D}$ and $1 \mathrm{~F}$ ) or FN (Fig. 2A to $2 \mathrm{E}$ ).

\section{Discussion}

The histological response to $\mathrm{CH}$ using these three
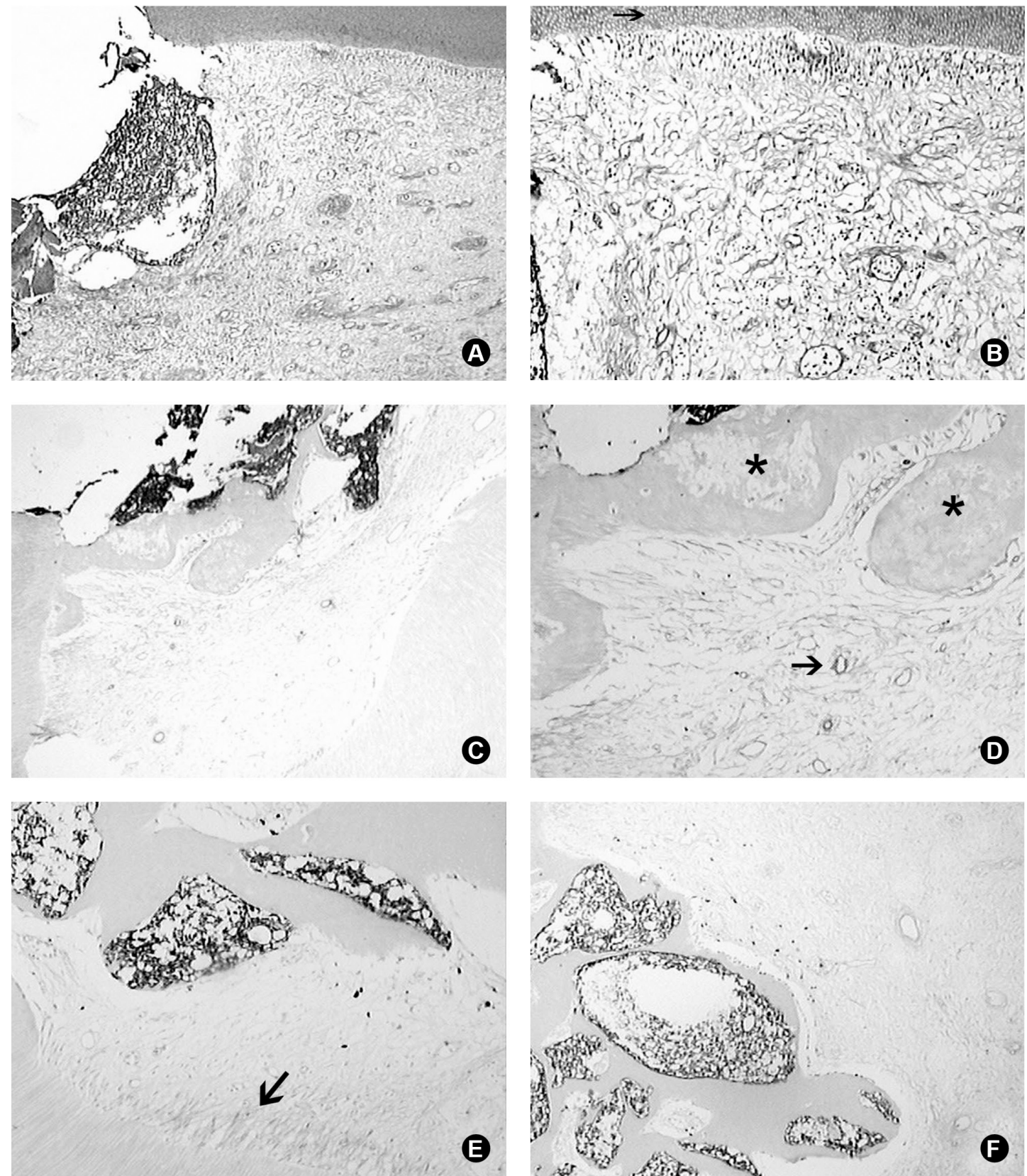

Figure 2. Immunohistochemical FN expression during pulp repair. A: Immunohistochemical expression of FN after 7 days (sodium hypochlorite), exhibiting a delicate fibril pattern in the entire pulp tissue. Perivascular internal controls are positive. No reactivity is observed for the physiologic dentin (40x). B: A closer view of 'A', at the interface between capping material and exposure site. Predentin is negative for FN (arrow) (100x). C: FN expression after 30 days (chlorhexidine) revealing a fibril pattern of expression in the pulp tissue, more evident near to the dentin barrier and around blood vessels. Dentin was negative for FN expression (40x). D: Higher magnification of 'C', emphasizing the more condensed FN expression in the pulp tissue near to the osteodentin barrier (*) and in the perivascular areas (arrow) (100x). E: Saline (90 days), a thin linear FN staining is observed, delimitating the inner area of the dentin barrier, being more evident in the interodontoblastic region (arrow) than in the predentin. No reactivity for FN was observed in the reparative dentin. F: Another view of panel A, without FN expression in the dentin barrier (100x). 
hemostatic agents was previously reported in another study (7). In summary, the hemostatic solutions used did not impair repair patterns process, with all pulps exhibiting dentin barrier formation and showing their biocompatibility (7).

The organic component of dentin can be dissolved by $5.25 \% \mathrm{NaOCl}(11)$. The differentiation of stem cells into odontoblast was observed on tooth-slice scaffolds treated with EDTA, but no differentiation was found in those cultured in tooth-slice scaffolds treated with $\mathrm{NaOCl}$, due to lack of inductive signals from denatured dentin disks (12). Considering that the pulp repair is related to growth factors released from dentin by $\mathrm{CH}(2)$, the removal of organic phase by the hemostatic agent could compromise repair, altering the expression of glycoproteins. However, it was shown that the used hemostatic solutions did not compromise the expression of both glycoproteins.

When comparing the expression of both glycoproteins, they had a similar expression pattern in the entire connective pulp tissue, in close proximity with collagen fibers, assuming a reticular pattern, and concentrating around blood vessels, as previously reported $(1,10,13,14)$. This pattern was expected, since these adhesive glycoproteins are compounds of the extracellular matrix of dental pulp $(1,13,15)$. The amount of these proteins inside pulp tissue could have a crucial role in the regulation of tissue structure (15). The abundance of TN in the pulp tissue is associated with the pulp cells ability to differentiate into odontoblast-like cells able to synthesize mineralized tissues (16).

This study also showed positive staining of both glycoproteins in the interodontoblastic region, in all investigated time periods, corroborating previous findings $(1,10,15,17)$. The positive staining for FN in this region corresponds to the von Korff fibers, acting as a scaffold for odontoblast-like cells elongation and migration, contributing to the maintenance of specific cell morphology, due to the attachment to the distal odontoblastic pole (14). FN immunohistochemical expression was detected in the interodontoblastic area indicating its role in the initialization of mineral formation (17). It is reasonable to conclude that analogous to the primary odontogenesis, a FN-rich matrix may have an important role in reparative dentinogenesis, and this FN-rich matrix could serve as a growth factor reservoir $(1,10,14)$. It has been demonstrated previously that FN gene expression was stimulated in pulp cells by calcium ions (released from $\mathrm{CH}$ materials) (18). FN may have induced differentiation of pulp cells in mineralized tissue forming cells, responsible for dentin barrier formation. At 7 days, in the exposure site, TN and FN expression were detected in the subjacent region $(1,10,14)$.

The results of the present study reinforce the belief that reparative dentinogenesis recapitulate the primary dentinogenesis (15). During tooth development, TN and FN are located in the basal membrane and they could be enrolled in the alignment and differentiation of cells from dental papilla in odontoblasts (16), in the presence of growth factors (15). During pulp repair, a fibrin and FN network in contact with $\mathrm{CH}$ cement crystals, could mediate the migration, proliferation and adhesion of cells that synthesize a fibrodentin matrix rich in $\mathrm{FN}$, culminating with the differentiation in odontoblast-like cells (14). Therefore, FN-rich fibrodentin could have a function similar to the basal membrane, and the adhesive properties of FN may provide interaction between odontoblast-like cells and the primitive matrix.

As an anti-adhesive glycoprotein, TN acts modulating the adhesive relation between cells that originate the odontoblast-like cell and the FN-rich layer, allowing its migration, and creating a less resistant way through the FNrich matrix (14). Such fact could explain the coexpression of both glycoproteins with antagonist functions in the repair at the pulp exposure site (10).

After 30 days, there was positive immunoreactivity for $\mathrm{TN}$ and $\mathrm{FN}$, delimitating and lining the subjacent region of the dentin barrier, as well as reactionary dentin (10). TN acts during tooth embryogenesis and it persists in the dental pulp but it is downregulated in odontoblasts (20). Since $\mathrm{CH}$ capping can release growth factors present within the dentin (2), and the gene expression of fibronectin was increased in pulp cells in contact with calcium ions (18), these released growth factors might stimulate TN expression (10). Dental pulp stem cells could be induced into dentinsecreting odontoblast-like cells after stimulation by isolated dentin matrix components, with several genes upregulated during this process, including TN (20). TN was not expressed in the dentin barrier at a 90-day interval, neither in the physiological or reactionary dentin $(1,10,15)$.

At 30 days, FN was not observed in reparative or reactionary dentins. However, the subjacent pulp tissue and the fibrodentin were positive to FN. Similar FN patterns were observed in another study within the same period, with expression surrounding cells embedded in the irregularly deposited dentin matrix (14). These findings reinforce the key role of FN in odontoblast differentiation and in the maintenance of the odontoblast-like cell morphology, aligned under the dentin barrier. The presence of FN at the predentin is still controversial. During tooth development in rats, FN was found in the predentin of the initial stages and it was absent in the predentin where odontoblasts were completely differentiated (16). While some authors suggested that FN is not present in human predentin (15), others have shown its expression in human predentin, correlating its action in the adhesivity between the odontoblast layer and the non-mineralized matrix $(1,10,14)$. 
In addition, interodontoblastic collagen fibers associated to FN were observed penetrating predentin (17), which was also detected in the present study. However, in this study, there was no clear and uniform staining of $\mathrm{FN}$ in predentin, with some areas presenting positive and others negative expression. In summary, the results for TN and FN expression in human pulps are quite similar to those described when swine pulps were capped with $\mathrm{CH}(1)$.

The understanding of the extracellular matrix's role during reparative/regenerative process may be crucial to optimize the present strategies of vital pulp therapy $(1,21)$ and to help in the development of future strategies, especially those based on the development of dental pulp by tissue engineering $(12,22,23)$.

In conclusion, the findings of this study show that the different hemostatic agents did not influence the patterns of TN and FN expression during repair of pulps capped with $\mathrm{CH}$. Also, considering the different evaluated periods of time, it was possible to observe that both glycoproteins were expressed in pulp tissue, especially under the formed dentin barriers, although they were not present in mineralized tissues.

\section{Resumo}

Este estudo investigou a expressão das glicoproteinas Tenascina (TN) e Fibronectina (FN) da matriz extracelular no reparo pulpar após capeamento com hidróxido de cálcio $(\mathrm{HC})$, seguindo diferentes protocolos de hemostasia. Cavidades de classe I com exposição pulpar foram preparadas em 42 terceiros molares humanos indicados para extração. Diferentes agentes hemostáticos (solução salina a 0,9\%, hipoclorito de sódio a $5,25 \%$ e clorexidina a $2 \%$ ) foram usados e as polpas foram capeadas com cimento de HC. Após 7, 30 ou 90 dias, os dentes foram extraídos, fixados em formalina e preparados para análise imunoistoquímica. Os agentes hemostáticos não influenciaram a expressão de TN e FN. Ambas glicoproteinas foram encontradas em todo tecido pulpar, ao redor das fibras colágenas e estiveram ausentes nos tecidos mineralizados. Na pré-dentina, a TN mostrou forte imunoexpressão e a FN teve uma expressão variável. Após 7 dias, foi observada uma expressão levemente mais pronunciada no lugar da exposição pulpar. Aos 30 dias, a TN e a FN demonstraram uma expressão mais forte sob a barreira dentinária e aos 90 dias, uma expressão fina e linear da TN e FN apresentava-se delimitando a dentina reparativa. Em conclusão, os agentes hemostáticos não influenciaram e expressão da TN e da FN. A imunoexpressão da TN e FN foi observada em diferentes regiões e periodos, demonstrando o seu papel no reparo pulpar.

\section{References}

1. Leites AB, Baldissera EZ, Silva AF, Tarquinio S, Botero T, Piva E, et al.. Histologic response and tenascin and fibronectin expression after pulp capping in pig primary teeth with mineral trioxide aggregate or calcium hydroxide. Oper Dent 2011;36:448-456.

2. Graham L, Cooper PR, Cassidy N, Nor JE, Sloan AJ, Smith AJ. The effect of calcium hydroxide on solubilization of bio-active dentine matrix components. Biomaterials 2006;27:2865-2873.

3. Stanley HR. Criteria for standardizing and increasing credibility of direct pulp capping studies. Am J Dent 1998;Spec No:S17-S34.

4. Elias RV, Demarco FF, Tarquinio SB, Piva E. Pulp responses to the application of a self-etching adhesive in human pulps after controlling bleeding with sodium hypochlorite. Quintessence Int 2007;38:e67-e77.

5. Accorinte $M$ de $L$, Loguercio $A D$, Reis $A$, Holland R. Effects of hemostatic agents on the histomorphologic response of human dental pulp capped with calcium hydroxide. Quintessence Int 2007;38:843-852.

6. Pameijer $\mathrm{CH}$, Stanley HR. The disastrous effects of the "total etch" technique in vital pulp capping in primates. Am J Dent 1998;Spec No:S45-S54.

7. Silva AF, Tarquinio SB, Demarco FF, Piva $E$, Rivero ER. The influence of haemostatic agents on healing of healthy human dental pulp tissue capped with calcium hydroxide. Int Endod J 2006;39:309-316.

8. Bonecker M, Mantesso A, de Araujo NS, Araujo VC. Expression of proteins in the extracellular matrix of pulp tissue in human primary teeth during physiologic root resorption. Quintessence Int 2009;40:553-558.

9. Chiquet-Ehrismann R. What distinguishes tenascin from fibronectin? Faseb J 1990 4:2598-2604.

10. Piva E, Tarquinio SB, Demarco FF, Silva AF, de Araujo VC. Immunohistochemical expression of fibronectin and tenascin after direct pulp capping with calcium hydroxide. Oral Surg Oral Med Oral Pathol Oral Radiol Endod 2006;102:e66-e71.

11. Beltz RE, Torabinejad M, Pouresmail M. Quantitative analysis of the solubilizing action of MTAD, sodium hypochlorite, and EDTA on bovine pulp and dentin. J Endod 2003;29:334-337.

12. Casagrande L, Demarco F, Zang Z, Araujo F, Nör J. Effect of Dentin Treatments and Dentin-Derived BMPs on SHED Differentiation. J Dent Res 2010;89:603-608.

13. Martinez EF, Machado de Souza SO, Correa L, Cavalcanti de Araujo V. Immunohistochemical localization of tenascin, fibronectin, and type III collagen in human dental pulp. J Endod 2000;26:708-711.

14. Yoshiba K, Yoshiba N, Nakamura H, Iwaku M, Ozawa H. Immunolocalization of fibronectin during reparative dentinogenesis in human teeth after pulp capping with calcium hydroxide. J Dent Res 1996;75:1590-1597.

15. Lukinmaa PL, Mackie EJ, Thesleff I. Immunohistochemical localization of the matrix glycoproteins--tenascin and the ED-sequencecontaining form of cellular fibronectin--in human permanent teeth and periodontal ligament. J Dent Res 1991;70:19-26.

16. Thesleff I, Mackie E, Vainio S, Chiquet-Ehrismann R. Changes in the distribution of tenascin during tooth development. Development 1987;10:289-296.

17. Kitasako $Y$, Shibata $S, \operatorname{Cox} C F$, Tagami J. Location, arrangement and possible function of interodontoblastic collagen fibers in association with calcium hydroxide-induced hard tissue bridges. Int Endod J 2002;35:996-1004.

18. Mizuno $M$, Banzai $Y$. Calcium ion release from calcium hydroxide stimulated fibronectin gene expression in dental pulp cells and the differentiation of dental pulp cells to mineralized tissue forming cells by fibronectin. Int Endod J 2008;41:933-938.

19. Goldberg M, Smith AJ. Cells and extracellular matrices of dentin and pulp: a biological basis for repair and tissue engineering. Crit Rev Oral Biol Med 2004;15:13-27.

20. Liu J, Jin T, Chang S, Ritchie HH, Smith AJ, Clarkson BH. Matrix and TGF-beta-related gene expression during human dental pulp stem cell (DPSC) mineralization. In Vitro Cell Dev Biol Anim 2007;43:120-128.

21. Dantas RV, Conde MC, Sarmento HR, Zanchi CH, Tarquinio SB, Ogliari FA, et al.. Novel experimental cements for use on the dentin-pulp complex. Braz Dent J 2012;23:344-350.

22. Demarco FF, Casagrande L, Zhang Z, Dong Z, Tarquinio SB, Zeitlin BD, et al.. Effects of morphogen and scaffold porogen on the differentiation of dental pulp stem cells. J Endod 2010;36:1805-1811.

23. Demarco FF, Conde MC, Cavalcanti BN, Casagrande L, Sakai VT, Nör JE. Dental pulp tissue engineering. Braz Dent J 2011;22:3-13.

Received January 24, 2013 Accepted April 17, 2013 